\title{
Development of the Financial System in India: Assessment of Financial Efficiency, Stability, Regulation and Supervision
}

\author{
Sanjoy Kumar Saha \\ Assistant Professor, Department of Economics \\ Mawlana Bhasani Science and Technology University \\ Santosh, Tangail-1902, Bangladesh \\ Email: sanjoykumarsaha@yahoo.com \\ Md. Rashidul Hasan \\ Assistant Professor, Agribusiness and Marketing Department \\ Sher-e-Bangla Agricultural University, Dhaka, Bangladesh \\ Email: rashidul_prince@yahoo.com
}

Doi:10.5901/ajis.2013.v2n3p219

\begin{abstract}
In this paper we will analyze the efficiency and stability of the Indian financial system using several indicators from the Global Financial Development database of the World Bank. In addition, we will briefly look at the concentration and composition of the banking sector in India. Lastly, the regulation and supervision of the financial sector in India will be discussed using the 2011 Bank Regulation and Supervision Survey of the World Bank. Germany is used as benchmark country. We have found that in terms of financial institutions and markets India's development is noticeable. Banking sector in India was more robust than that of Germany in case of gaining profit. Indian stock market is also increasing their financial efficiency. Banking sector has been supervised and regulated quite well in the last decade. But quality of assets has been deteriorating in India due to increasing non performing loans. As a result liquidity risk increased.
\end{abstract}

Keywords: Efficiency; interlinkage; capital flight; depositor; volatile; bubbles.

\section{Introduction}

India has made remarkable progress toward developing a stable financial system. Since liberalization in the early 1990s, the system's growth and increasing commercial orientation have been accompanied by steady improvements in the legal, regulatory, and supervisory framework. The Indian economy and its financial system weathered the global financial crisis well—due to strong balance sheets and profitability entering the crisis, a robust regulatory framework, and timely actions to counter pressures on liquidity, the supply of credit, and aggregate demand. The prominent role of the state in the financial sector-through ownership of large financial institutions, captive government financing, directed credit to priority sectors, tight controls over the range of allowable activities, and restrictions on the availability of foreign capitalcontributes to a build-up of fiscal contingent liabilities and creates a risk of capital misallocation that may constrain economic growth. Gradually reducing mandatory holdings of government securities by financial institutions, and allowing greater access to private (domestic and foreign) sources of capital, would provide greater room for the financial sector to intermediate funds toward productive economic activities, thereby improving prospects for sustained growth. The system is also becoming more complex-interlinkages across markets and institutions as well as across borders are growing. The combination of a sharp credit expansion and a more recent economic slowdown is putting pressure on banks' asset quality, especially for infrastructure and priority sector lending. Group concentrations have reached troubling levels at some banks.

The outline of the paper is as follows: second section explains efficiency of the financial system in India, third section is about financial stability. Fourth section analyzes bank concentration and decomposition and fifth section explains bank regulation and supervision in India. 


\section{Efficiency}

In the section below, we will discuss the efficiency of the financial system in India and compare it with Germany. Both financial institution efficiency and financial market efficiency are analyzed. The efficiency measures give an indication of the cost of financial intermediation (Cihàk et al., 2012).

\subsection{Financial institution efficiency}

The following indicators will be looked at in more detail: the net interest margin, the percentage non-interest income in total income, the return on equity and the cost to income ratio.

\subsubsection{Net interest margin and non-interest income to total income}

Figure 1: Net interest margin (NIM) (\%) and non-interest income to total income (\%)
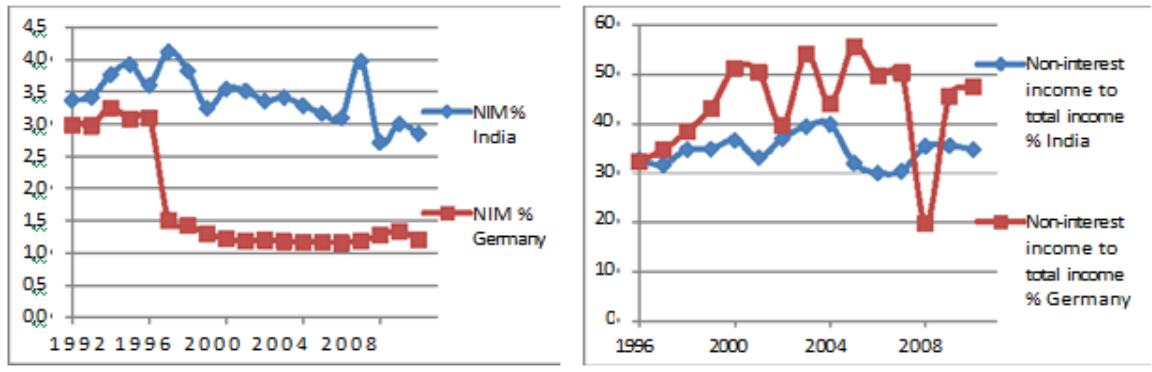

Remark: For Germany, there must have been a redefinition of the NIM or a change in measurement between 1996-1997.

\section{Source: World Bank GFDD}

The net interest margin (NIM) captures the interest income of the banks on loans or other assets minus the interest costs that the bank paid on its deposits or other funding divided by the total average amount of assets on which it earned income in that time period. The net interest margin in India decreased gradually over the last 20 years (down from 3.55\% at end-2000 to 2.85\% at end-2010), but is still much higher than in Germany (on average 1.21\% during 2000-2010). This implies that the net cost of financial intermediation through banks is higher in India: borrowers pay on average a higher interest rate and depositors receive on average a lower interest rate. Remark that there must have been a redefinition or a change in measurement of the net interest margin in 1997 for Germany and this explain the drop from 3.38\% at end1996 to $1.41 \%$ at end-1997. According to the Deutsche Bundesbank, the net interest margin for all banks between 19921996 was on average $1.80 \%$ and was stable during that period.

The evolution of non-interest income shows a volatile pattern for Germany and, to a lesser extent, for India. The main sources of non-interest income are from fees and commissions, trading activities and brokerage. In India, the share of non-interest income in total income was on average 34.57\% during 1996-2010, but peaked during 2002-2004 at $38.79 \%$, after which it declined to an average of $30.84 \%$ during $2005-2007$. The high level of non-interest income in 2004 might be explained by the good performance of the stock market that year. In Germany, the share of non-interest income in total income is higher compared to India with an average of 43.78\% during 1996-2010 and made up even more than $50 \%$ of total income during 2000-2001 and 2003-2007. The share of non-interest income dropped in 2002 (39.62\%) due to the stock market downturn (internet bubble bursting) and in 2008 (19.82\%) caused by the global financial crisis. 


\subsubsection{Return on equity and cost to income ratio}

Figure 2: Return on equity (\%) and cost to income ratio (\%)

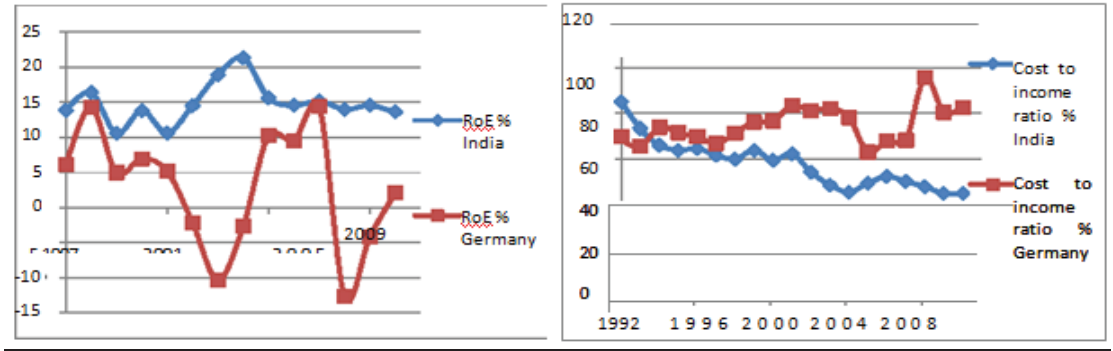

Source: World Bank GFDD

The indicators return on equity (RoE) and the cost to income ratio tell us more about the profitability and cost effectiveness of the banking sector.

The RoE, which is the ratio of net income to yearly averaged equity, is higher in India and remained always positive during the period 1997-2010. This indicates that Indian banks generated a higher profit on their shareholder's equity. For Indian banks, the RoE was on average 14.83\% with its lowest levels in 1999 \& 2001 (10.62\%) and highest levels in 2003-2004 (20.11\%) during which the share of non-interest income was also at its highest levels. One can see that Indian banks were not affected by the financial crisis at end-2007-2008. German banks' RoE was on average 3\% during 1997-2010, with peaks in 1998 (14.28\%) and 2007 (14.38\%) and falls in 2003 (-10.3\%), caused by the slowdown of the German economy (real GDP growth was $-0.1 \%$ in 2003) which resulted in large loan losses (IMF, FSSA Germany, 2003), and $2008(-12.67 \%)$, due to the global financial turmoil. The other profitability measure, return on assets (RoA) (not plotted here), which is the ratio of net income to yearly averaged total assets, showed a similar pattern as the RoE for each country and was on average $0.85 \%$ in India and $0.12 \%$ in Germany for the period 1997-2010.

The cost to income ratio shows opposite trends for India and Germany: while the ratio is generally declining in India (down from 85.12\% in 1992 to 45.07\% in 2010), it is increasing in Germany (up from 70\% in 1992 to $82.62 \%$ in 2010). Since 1994, Indian banks generate much more income for a given amount of costs and are thus more cost efficient. Unsurprisingly the cost to income ratio peaked at $95.80 \%$ at end-2008 for Germany, since income dropped sharply during the financial crisis. Another cost effectiveness measure, overhead costs to total assets (not plotted here), was both for India and Germany decreasing during 1992-2010 (down from 2.94\% to 1.69\% for India and down from $2.97 \%$ to $1.26 \%$ for Germany) but remained slightly higher for India, implying lower cost efficiency for Indian banks when expressed in terms of total assets.

\subsection{Financial market efficiency}

\subsubsection{Stock market turnover ratio: value traded / capitalization}

Figure 3: Stock market turnover ratio: value traded / capitalization

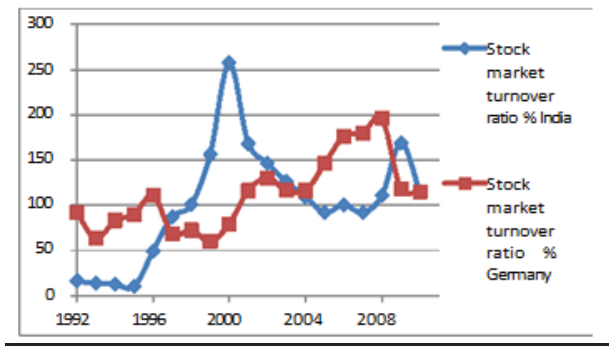

Source: World Bank GFDD 
The stock market turnover ratio is the total value of shares traded during the period divided by the average market capitalization for the period. The idea behind this ratio is as follows: the higher this turnover ratio, the more trading activity and thus the more liquid the stock market, so consequently the more efficient the market (Cihàk, 2012). For India, the stock market turnover ratio increased strongly from a low $16.63 \%$ at end-1992 to a peak of as much as $257.57 \%$ at end2000 , illustrating the rapid speed of development of the stock market. After this record-high at end-2000, the turnover on the stock market gradually decreased to $91.92 \%$ at end-2005 and remained around 100\%, except in 2009 when it jumped temporarily to $168.83 \%$, which can be explained by portfolio outflows as most financial institutions (banks \& non-banks) in developed countries were deleveraging (IMF, WEO, 2010) (the S\&P BSE 500 dropped from almost 9000 at begin-2008 to around 3000 at begin-2009 but recovered quickly to approximately 7000 at begin-2010). For Germany, the stock market turnover was at the beginning of the 90 s at a much higher level compared to India (92.18\% at end-1992), and was less volatile during 1992-2010, with a peak of $195.83 \%$ at end-2008, caused by panic sales on the stock market (the DAX dropped from almost 8000 at begin-2008 to approximately 4700 at end-2008), and falls of $63.12 \%$ at end-1993 and $60.05 \%$ at end-1999.

\section{Stability}

\subsection{Financial institution stability}

Financial stability deals with indicators which assesses the financial sector, (the banking system in our case) to see whether it is stable or it is evolving to any distress (or a crisis). It is also, "a part of the broader financial development process" (Čihák \& al, 2012). In the lines to follow, we'll be analyzing India and Germany Z-score which is the common variable used to measure financial stability as point out by Činák \& al (2012), as well as other variables such as bank credit to bank deposits, liquid assets to deposits and short term funding, etc, also called indicators of soundness.

\subsubsection{Bank Z-score and Bank credit to bank deposits}

Figure 4: Bank Z-score and bank credit to deposits

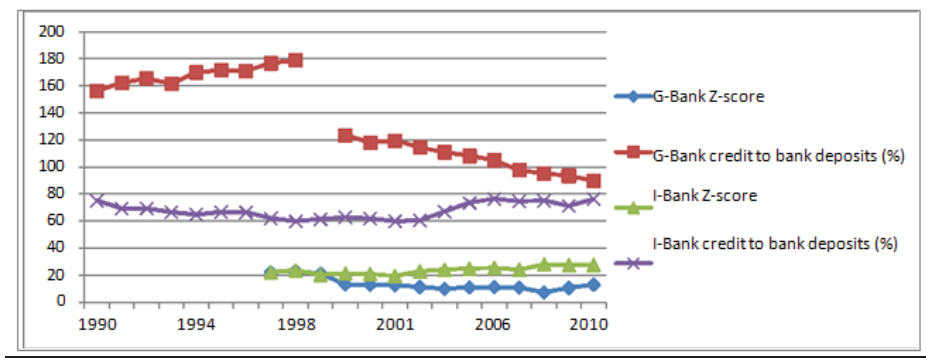

Source: World Bank GFDD

The Z-score is a key variable on financial stability that compares buffers (capitalization and returns) with the potential for risk (volatility of returns). It is inversely related to the probability of a financial institution's insolvency, i.e. the probability that the value of its assets becomes lower than the value of its debt (Čihák \& al, 2012). As we can see from the graph above, from 1997 to 1999, the Z-score in India and Germany were practically the same, but after this period India Z-score (in green) experienced an increase from 20,4 in 1999 to 28 in 2010, while that for Germany (in blue) started to fall from 21,3 to 7,4 in 2008. Meaning that, the banking system of Germany was more exposed to insolvency issues during this period, while India's banking sector stability was moderately strengthening. Indeed, this is in line with a finding of Poghosyan \& Cihák, (january 2009, P9-10) that stipulates that, most of the 79 distress episodes for 54 EU banks occurred in Germany between 1997 to 2008. After the global financial crisis of 2008, Germany Z-score improved by increasing up to 13 in 2010.

Bank credit to deposits is the financial resources provided to the private sector by domestic money banks as a share of total deposits. Bank credit to bank deposits in Germany is quite high compared to that for India during the 19902010 period. It increases from 156\% to 178\%, during 1990-1998 period and decreases from 123 to 89 in 2000-2010 period; meaning that, during this period, German banks were decreasingly financing the private sector. And, as we saw 
with the Z-score, this might also be explained by the distress episodes faced by German banks over the 1997-2008 period. In India, we do observe a decrease of $19.6 \%$ of this indicator from 1990 to 2003 , followed by an increase from $60,4 \%$ in 2003 to $76,3 \%$ in 2010. This is quite in line with the growth in GDP per capita which was on average $6.6 \%$ during 2003-2010. Indeed, as argued by Honohan \& Beck (2007), credit to the private sector is most closely correlated with economic growth as this variable measures the degree to which savings are allocated to productive uses which can stimulate economic growth. Furthermore, this rise in the India Bank credit to bank deposits is also consistent with the fact that, "Credit and deposit growth in the banking sector have decelerated while banks' reliance on borrowed funds has increased" (India's Central Bank, 2012).

\subsubsection{Liquid assets to deposits and short term funding}

Figure 5: Liquid assets to deposits and short term funding

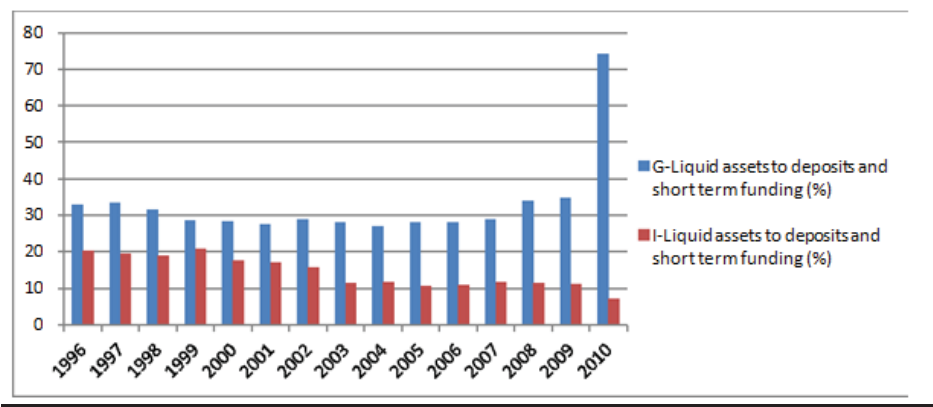

Source: World Bank GFDD

Liquid assets to deposits and short term funding are the ratio of the value of liquid assets to short-term funding plus total deposits. It shows the ability of a bank to repay its liabilities that can be claimed at short notice with its cushion of cash and with the assets that can be readily monetized (Angora \& Roulet 2011, P10). The higher is the ratio, the more a bank is able to repay its short term liabilities with the liquid assets from its balance sheet. Thus we can see from the graph above that, this indicators has been decreasing in India during the 1996-2010 period from 20\% to less than 10\%, Indian banks were more and more exposed to distress while there was a fortune reversal in Germany, where this indicator decreased slightly from $32 \%$ in 1996 to $27 \%$ in 2004, following by an increase from that level to $34 \%$ in 2009 and a quick jump up to $74 \%$ in 2010 . This sudden rise might be the results of the substantial public intervention and balance sheet contraction after the global financial turmoil of 2008. In fact, from October 2008 to December 2010, the German federal government established the Sonderfonds Finanzmarktstabilisierung (SoFFin), a $€ 480$ billion rescue package to provide guarantees and recapitalization, as well as funds for asset relief measures (IMF, 2011). And as pointed out by the authors, "These measures have successfully stabilized the German financial sector".

\subsubsection{Regulatory capital to risk-weighted assets}

Figure 6: Regulatory capital to risk-weighted assets

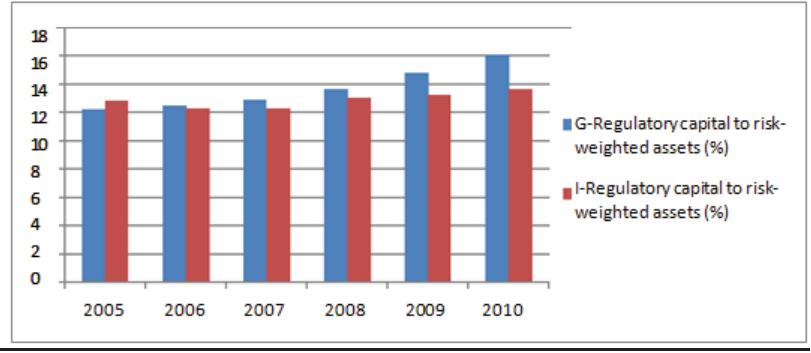

Source: World Bank GFDD 
It is a ratio of total regulatory capital to its held assets, weighted according to the risk of those assets. Angora \& Roulet (2011) showed econometrically that, the bank probability of default is negatively related with the level of bank capitalization at risk. Meaning that, the more the T12_RWA, the lower the probability of a bank to default. Thus, as the graph above shows, the T12_RWA in India and Germany had almost the same pattern from 2005 to 2008 . But certainly thanks to exceptional government's measures to rescue its banking system after the 2008 crisis, Germany's bank capitalization relative to the risk improved significantly from $13,6 \%$ to $16,1 \%$ (and became one of the highest in EU) during the 2008-2010 period (IMF, 2011). During the same period in India, this indicator slightly increased by 4,6\% and remains lower than that for Germany.

\section{Bank Concentration and Composition}

\subsection{Bank asset concentration (5 largest) and percentage of foreign banks among total banks}

Figure 7: Bank asset concentration (5 largest banks) and percentage of foreign banks among total banks.

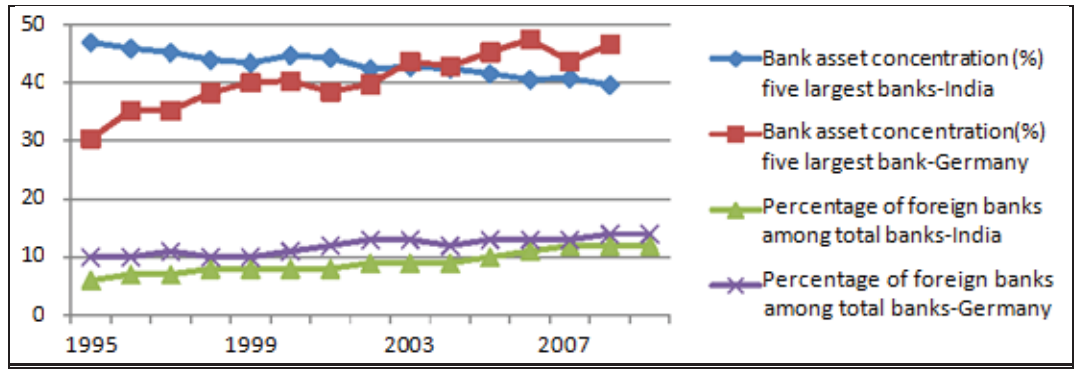

Source: World Bank GFDD

Bank concentration of five largest banks (\%) means that assets of five largest commercial bank as a share of total commercial bank assets. We see from the above table that bank asset concentration for the five largest banks was above $46 \%$ in the year 1997 in India. In the year 2001, it was above $43 \%$ and increased above $44 \%$ in the year 2002. Then the percentage became decreasing and it was above $39 \%$ in the year 2010. On the other hand bank asset concentration for the five largest banks was above $30 \%$ in the year 1997 in Germany, and then the trend reached above $35 \%$ in the year 1999. The trend was increasing gradually from the year 2000 to the year 2008 but there were some fluctuations in the trend. The trend decreased a little bit in the year 2009 and the figure was above $43 \%$. Finally the trend increased above $46 \%$ in the year 2010. Bank asset concentration for five largest banks in Germany was above India after 2004. Finally we can say that bank concentration for five largest banks was decreasing over time which means that competitiveness in banking sector in India is increasing over time.

On the other hand, Percentage of foreign banks among total banks means percentage of the number of foreign owned banks to the number of the total banks in an Economy. A foreign bank is a bank where 50 percent or more of its shares are owned by foreigners.

From the above table we see that percentage of foreign banks among total banks was increasing gradually in India from 1995 to 2009. The value of the trend was 6, 8, 9 and 12 for the year 1995, 2001, 2004 and 2009 respectively. On the other hand percentage of foreign banks among total banks in Germany was also increasing over time but there were some fluctuations in the trend. It was 10 for the year 1995, 13 for the year 2003 and 14 for the year 2009. Foreign banks may cause financial instability.

"Given the importance of foreign banks in many countries, understanding the motivations of foreign banks to enter a particular host country, the mode by which they do so, and the impact they have on financial sector development and lending stability has become essential. We find that on average foreign banks reduced lending more compared to domestic banks during the global crisis. As such, foreign banks arguably contributed to financial instability"(Stijn and Neeltje, 2012). 


\section{Regulation and Supervision}

Bank regulation and supervision cover many aspects; but based on the global data base of the 2011 Bank Regulation and Supervision Survey of the World Bank, we will focus on the organization of capital adequacy and the organization of deposit insurance in India and Germany.

\subsection{Micro-prudential supervision in India and Germany}

First of all, it's important to point out that, micro-prudential supervision of banks in India is assured by the Reserve bank of India. This institution was established on April 1935, with the main objective of "regulate the issue of Bank Notes and keeping of reserves with a view to securing monetary stability in India and generally to operate the currency and credit system of the country to its advantage"1.

Thus, the Reserve Bank regulates and supervises India's financial system and in terms of micro-prudential supervision, they control: commercial banks and all other Indian development financial institutions, urban co-operative banks, Regional Rural Banks (RRB), District Central Cooperative Banks and State Co-operative Banks and Non-Banking Financial Companies (NBFC). In Germany this role is assured by the Federal Financial Supervisory Authority (BaFin).

\subsection{Organization of capital adequacy (India and Germany)}

Since 2007, the regulatory capital adequacy regime used in India and Germany is Basel II. That regime covers: credit risks, market risks and operational risks. Requirements and results of assessment of capital adequacy for India and Germany are summarized in the table below:

Table 1: Comparison of capital adequacy between India and Germany

\begin{tabular}{|c|c|c|c|c|}
\hline Indicators & \multicolumn{2}{|c|}{ Germany } & \multicolumn{2}{|c|}{ India } \\
\hline $\begin{array}{l}\text { Minimum risk-based regulatory capital ratio required at the end 2008-2010/ } \\
\text { Risk - based capital ratio }\end{array}$ & \multicolumn{2}{|c|}{$8 \%$} & \multicolumn{2}{|c|}{$9 \%$} \\
\hline 2008 & \multicolumn{2}{|c|}{$13,59 \%$} & \multicolumn{2}{|c|}{$0,00 \%$} \\
\hline 2009 & \multicolumn{2}{|c|}{$14,82 \%$} & \multicolumn{2}{|c|}{$14,00 \%$} \\
\hline 2010 & \multicolumn{2}{|c|}{$16,05 \%$} & \multicolumn{2}{|c|}{$14,50 \%$} \\
\hline Minimum required non risk-based regulatory capital ratio (2008-2010) & \multicolumn{2}{|c|}{ None } & \multicolumn{2}{|c|}{ None } \\
\hline \multirow[t]{2}{*}{ Application of minimum capital requirement } & \multicolumn{2}{|c|}{$\begin{array}{l}\text { At the Individual } \\
\text { bank level }\end{array}$} & \multicolumn{2}{|c|}{$\begin{array}{l}\text { At every banking } \\
\text { group or subgroup level }\end{array}$} \\
\hline & Min & $\operatorname{Max}$ & Min & Max \\
\hline $\begin{array}{c}\text { Tier } 1 \text { capital ratio required/ } \\
\text { Tier } 1 \text { capital ratio at the end } 2008-2010\end{array}$ & $4 \%$ & - & $6 \%$ & - \\
\hline 2008 & \multicolumn{2}{|c|}{$9,55 \%$} & \multicolumn{2}{|c|}{$0,00 \%$} \\
\hline
\end{tabular}

\begin{tabular}{|c|c|c|c|c|}
\hline 2009 & \multicolumn{2}{|c|}{$10,84 \%$} & \multicolumn{2}{|c|}{$9,60 \%$} \\
\hline 2010 & \multicolumn{2}{|c|}{$11,83 \%$} & \multicolumn{2}{|c|}{$10,10 \%$} \\
\hline Legally allowed in regulatory capital & Min & Max & Min & Max \\
\hline -Common equity & $2 \%$ & - & $0 \%$ & - \\
\hline -Tier 2 & $8 \%$ & $100 \%$ & $0 \%$ & $6 \%$ \\
\hline -Tier 3 & - & $250 \%$ & \multicolumn{2}{|c|}{ Not controlled } \\
\hline Fraction of revaluation gains allowed as part of capital & \multicolumn{2}{|c|}{$45 \%$} & \multicolumn{2}{|c|}{$0 \%$} \\
\hline
\end{tabular}

Source: World Bank Global Data Base of the 2011 Bank Regulation and Supervision Survey

We notice from the table above that, at $9 \%$, the minimum risk-based regulatory capital ratio required in India is higher than that of Germany ( $+1 \%$ compare to the one of Germany), and that since 2009 India' risk based capital ratio fulfills the 
requirements of Basel II. Moreover, with a risk -based capital ratio of $14 \%$ in 2010 ( $+0.5 \%$ compared to 2009), India is improving, and the difference of that ratio across the two countries is negligible (lower than 2\%).

Same results are found for tier 1 capital ratio, for which requirement is $6 \%$ in India and $4 \%$ in Germany; here also minimum requirements are different for the two countries and India is improving. In fact, in 2010 India realized a tier 1 ratio of $10.1 \%(+0.5 \%$ compared to the level of 2009$)$ and here also, the difference between India and Germany is negligible (1.73\% in 2010 in the favor of Germany). Therefore, it appears that Indian banks are doing quite well in terms of capital adequacy.

However, in 2008, India's micro-prudential supervision in terms of capital adequacy requirements was lax allowing the economy to run a $0 \%$ risk -based capital ratio and a $0 \%$ tier 1 capital ratio. That situation changed after the global financial crisis of 2007, but we think that, more restrictions should be put on the minimum requirements legally allowed for: common equity, tier 2, and tier 3 ratios in India which are still $0 \%$. In Germany, minimum requirement for common equity and tier 2 ratio are respectively $2 \%$ and $8 \%$. Moreover India does not control Fraction of revaluation gains as part of capital, while Germany does. Additional efforts should be done on that sense in India, concerning capital adequacy.

In addition a striking point on the comparison of the organization of capital adequacy supervision between India and Germany is that minimum capital requirement in India are applied at banking group or sub-group level, while in Germany they are applied at the individual bank level. Grouping the assessment of minimal capital requirement for banking group or subgroup, can hide information on individual banks that are not performing well. Knowing how banks insolvency or inefficiency can spread to one another, we think that, India should also adopt individual bank supervision for minimum capital requirement.

\subsection{Organization of the deposit insurance system}

Globally, a deposit insurance fund is an insurance fund that guarantees deposits at banks or other savings institutions up to a certain amount ${ }^{2}$. In this section, we discuss how the deposit insurance protection system for commercial banks is organized in India, while stressing on major differences between India and Germany's insurance deposit system (see table 2 in annex).

\subsubsection{Overview}

The 2011 Bank Regulation and Supervision Survey reveal that, both India and Germany have a deposit insurance protection system for commercial banks, but they function quite differently. In fact, In India, there is a legally separate deposit insurance agency that protects the commercial banks and a subsidiary of the Reserve Bank of India plays also that role (both are public institutions), while in Germany deposit insurance system is managed by the private sector ${ }^{3}$.

In both countries, these deposit insurance institutions have access to information's collected by banking supervisors, have the power to cancel or revoke deposit insurance for any participating bank, but are not allowed use deposit insurance fund for purposes other than depositor protection (e.g. liquidity provision to banks). In addition, these institutions don't cover interbank deposits, deposits of the foreign branches of domestic banks, deposits of the foreign subsidiaries of domestic banks.

However, there are many differences in the system functioning across the two countries. Concerning the membership coverage field, in Germany, every bank in the territory is obliged to participate in the insurance deposit system, while in India, that participation is optional for foreign banks subsidiaries. Moreover, India's system managed insurance funds per depositors while Germany did the same per account. The percentage of the total deposits of participating commercial banks covered by the scheme decreased of $21.12 \%$ between 2008 and 2010 in India, moving from $56.17 \%$ to $36.67 \%$ in 2009 , to reach later on $35.05 \%$ in 2010. The high level of coverage observed in 2008 , could be explained by safety net put in place during the global financial crisis.

5.3.2 Positive points in the organization of India's deposit insurance system compared to that of Germany

\footnotetext{
${ }^{2}$ http://www.investorwords.com/7121/Deposit_Insurance_Fund.html

${ }^{3}$ In Germany, for commercial banks two statutory protection systems exist: the "Entschädigungseinrichtung deutscher Banken (EdB)" for private commercial banks and the "Entschädigungseinrichtung Öffentlicher Banken (VÖB)" for the public commercial banks. For private commercial banks a voluntary deposit protection fund is set up at the Association of German Banks (Bundesverband deutscher Banken) while for public commercial banks the corresponding voluntary deposit protection fund is set up at the Federal Association of Public Banks (Bundesverband Öffentlicher Banken Deutschland).
} 
The positive points in the organization of India's deposit insurance system compared to that of Germany are that: At the end of 2010, In India, ratio of accumulated funds to total bank assets was $0.85 \%, 0.35 \%$ more than that of Germany, showing a relatively good capacity of the country to cover participatory banks. Besides, in case of insufficient funds of the deposit insurance institutions to refund depositors, deposit insurance institutions of India have the possibility to borrow from reserve bank of India, while in Germany it is not the case; they can only borrow to banks on the shortfall. It means that, in case of systemic crisis, German Insurance deposits institutions may have difficulties to pay back depositors in the short run because the banking system is in crisis, while in India, that situation is less likely to happen, since deposit insurance companies can borrow directly from the Reserve Bank.

\subsubsection{Negative points in the organization of India's deposit insurance system compared to that of Germany}

The main negative point of India's deposit insurance system is that, the number of days where the deposit insurance scheme is legally obligated to fully reimburse insured depositors is 150 days, 7.5 times longer than that of Germany. In time of crisis in India, banks can easily collapse due to the relatively long delay between the crisis and the compensation by the deposit insurance system. Another striking negative point of India's Insurance deposit system is that, unlike Germany, it covers deposits denominated in foreign currency; this is quite bad because it can encourage banks and economic agents, to keep more foreign currency, which is not good for the economy.

\section{Conclusion}

Based on our analysis above, we can conclude that the financial sector in India has made significant improvements in efficiency, both for financial institutions and markets. The Indian banking system is still dominated by public banks, but is judged to be quite competitive with the presence of public, private and foreign banks (BIS, 2001). While the net interest margin of Indian banks still doubles that of German banks, it is on a decreasing trend, the cost of financial intermediation through banks is thus still high but reducing. The profitability of Indian banks is much higher than their German counterparts with an average return on assets and return on equity respectively seven and five times higher during 19972010 and more stable. Cost effectiveness measures have been improving as well. Stock market efficiency in India is also high, with trading activity and liquidity at elevated levels.

The Indian financial system has been stable during the past decades and has not faced any major banking crises. Credit risk ratios have been ameliorating: non-performing loans reduced by half between 2005- 2010 (from 5.2\% to 2.4\%) and the bank Z-score of Indian banks increased during 1997-2010, indicating a lower probability of insolvency. Liquidity ratios on the other hand have deteriorated with the ratio of liquid assets to deposits and short term funding decreasing during 1996-2010 and being much below Germany's ratio. Capital ratios increased and are well above the minimum required capital ratio of $9 \%$ (at end-2010 at 14\% with Tier I at 10\% (IMF, 2011)).

India has a long history of regulation and supervision and commits itself to align with international best practices (BIS, 2001). The Reserve Bank of India, India's central bank, supervises the banking sector and implemented Basel II in March 2009. Deposit insurance was introduced as early as 1962.

Overall, we can conclude that risks to the financial stability in India seem low during our period of analysis and regulation and supervision are strong. However in recent years, 2011-2012, asset quality has been deteriorating considerably (non-performing loans and restructured loans rose to respectively 3,2\% and 5.4\% of total loans at end-2012) and liquidity risk increased (IMF, 2013). The recent financial system stability assessment of IMF concluded "Despite these recent successes, India's financial sector still confronts longstanding impediments to its ability to support growth as well as new challenges to stability" (IMF, FSSA, 2013).

\section{References}

BIS, 2001, "The banking industry in the emerging market economies: competition, consolidation and systemic stability", BIS Papers No. 4.

Cihàk M., Demirgüç-Kunt A., Feyen E. and Levine R., 2012, "Benchmarking Financial Systems around the World", Policy research working paper 6175 , the World Bank.

Claessens Stijn, and Neeltje van Horen, 2012, "Foreign banks: Trends, Impact and Financial Stability", IMF Working Paper.

Claessens Stijn and Luc Laeven, 2004, "What Drives Bank Competition: Some International Evidence", Journal of Money, Credit and Banking 36: 563-83.

IMF, 2003, "Germany: Financial System Stability Assessment", IMF Country Report No. 03/343. IMF, 2010, "World Economic Outlook: 
Recovery, Risk \& Rebalancing".

IMF, 2011, "India: 2010 Article IV Consultation", IMF Country Report No. 11/50.

IMF, 2013, "India: Financial System Stability Assessment", IMF Country Report No. 13/8. IMF, 2013, "India: 2012 Article IV Consultation", IMF Country Report No. 13/37. http://www.bloomberg.com/quote/BSE500:IND http://www.boersefrankfurt.de/en/equities/indices/dax+DE0008469008

http://www.bundesbank.de/Navigation/EN/Statistics/Banksandotherfinancialinstitutions/Banks/Statisticsofthebanksprofitandlossaccounts/ tables/tabellen.html

\section{Annex}

Table 2: Comparison between India' and Germany Insurance deposit system

\begin{tabular}{|c|c|c|}
\hline Indicators & Germany & India \\
\hline Management of insurance funds & Private sector alone & Public sector alone \\
\hline Role deposit insurance agency & $\begin{array}{l}\text { Bank examination authority, authority to access } \\
\text { information collected by banking supervisors, } \\
\text { power to cancel or revoke deposit insurance for } \\
\text { any participating bank }\end{array}$ & $\begin{array}{l}\text { authority to access information collected } \\
\text { by banking supervisors, power to cancel or } \\
\text { revoke deposit insurance for any } \\
\text { participating bank }\end{array}$ \\
\hline $\begin{array}{l}\text { participation in the deposit insurance } \\
\text { system is compulsory }\end{array}$ & $\begin{array}{l}\text { For every banks in the country (Domestic banks, } \\
\begin{array}{l}\text { Foreign bank subsidiaries, Foreign bank } \\
\text { branches) }\end{array}\end{array}$ & $\begin{array}{l}\text { Not compulsory for } \text { Foreign bank } \\
\text { subsidiaries }\end{array}$ \\
\hline $\begin{array}{l}\text { The deposit insurance coverage type } \\
\text { is }\end{array}$ & Per depositor account & Per depositor \\
\hline \multicolumn{3}{|c|}{ Percentage of the total deposits of participating commercial banks covered by the scheme as of end of... } \\
\hline 2008 & - & $56.17 \%$ \\
\hline 2009 & - & $36.67 \%$ \\
\hline 2010 & - & $35.05 \%$ \\
\hline $\begin{array}{l}\text { Ex ante fund/reserve to cover deposit } \\
\text { insurance claims in the event of the } \\
\text { failure of a member bank is provided } \\
\text { by }\end{array}$ & The government alone & Government and banks \\
\hline $\begin{array}{l}\text { Ratio of accumulated funds to total } \\
\text { bank assets as of end of } 2010\end{array}$ & $0.5 \%$ & $0.85 \%$ \\
\hline $\begin{array}{l}\text { Events that triggers a claim for } \\
\text { payment by the deposit insurance } \\
\text { system }\end{array}$ & $\begin{array}{l}\text { Banking supervisor decision (not court-declared } \\
\text { bank bankruptcy, Deposit insurance agency/fund } \\
\text { administrator decision) }\end{array}$ & \begin{tabular}{|l} 
Banking supervisor decision (not court- \\
declared bank bankruptcy, Deposit \\
insurance agency/fund administrator \\
decision)
\end{tabular} \\
\hline $\begin{array}{l}\text { days is the deposit insurance scheme } \\
\text { is legally obligated to fully reimburse } \\
\text { insured depositors }\end{array}$ & 20 & 150 \\
\hline $\begin{array}{l}\text { when the deposit insurance fund is } \\
\text { insufficiently large to be able to fully } \\
\text { refund depositors }\end{array}$ & Its call on banks for the shortfall to borrow money & Borrow from reserve bank of India \\
\hline $\begin{array}{l}\text { Deposits excluded from deposit } \\
\text { insurance coverage }\end{array}$ & $\begin{array}{l}\text { Foreign currency deposits, Interbank deposits, } \\
\text { Deposits of the foreign branches of domestic } \\
\text { banks, deposits of the foreign subsidiaries of } \\
\text { domestic banks }\end{array}$ & $\begin{array}{l}\text { Interbank deposits, Deposits of the foreign } \\
\text { branches of domestic banks, deposits of } \\
\text { the foreign subsidiaries of domestic banks }\end{array}$ \\
\hline
\end{tabular}

Source: World Bank Global Data Base of the 2011 Bank Regulation and Supervision Survey 